\title{
ANALISA SISTEM PENCATATAN DAN MONITORING PIUTANG LEASING
}

\author{
Sukemi Kamto Sudibyo, Tantik Sumarlin \\ Jurusan Komputerisasi Akuntansi Sekolah Tinggi Elektronika Dan Komputer, Semarang \\ sukemi@gmail.com; Tantiksumarlin@gmail.com
}

\begin{abstract}
This research was made with the aim to help companies in controlling receivables. The study was conducted on companies engaged in the sale and purchase of motorcycles. These companies act as suppliers of goods and collaborate with credit financing institutions or what is commonly called leasing. Every credit sale will form a lease receivable that must be paid by the related leasing party. In general, many receivables have not been paid from the due date of the agreement. This impedes the company's financial productivity. From these problems, researchers create a system that can be used to meet the needs of the company, in relation to receivables. Researchers create a system that can improve performance to be more effective and dynamic, especially to record the daily control of receivables, namely by using the Leasing Accounts Recording and Monitoring System.

The design of recording and monitoring systems for receivables is made using the direct recording method. Systems development methods using the $R \& D$. Method stages in the $R \& D$ method include potential problems, information gathering, product design, design validation, design improvement, product testing, product revision, trial use, mass product manufacturing. The design of a monitoring system for leasing receivables billing, can help companies control receivables. Leasing Receivables Recording and Monitoring System can minimize receivables losses.
\end{abstract}

Keywords: Recording System, Receivable Collection, Leasing Receivables.

\section{PENDAHULUAN}

\subsection{Latar Belakang}

Tujuan utama didirikannya sebuah perusahaan adalah untuk mendapatkan laba atau keuntungan yang optimal dengan memanfaatkan sumber daya yang ada secara efektif dan efisien. Pencapain hasil dalam penjualan yang diperoleh perusahaan didapat dari hasil total penjualan barang dan atau jasa yang dihasilkan. Penjualan yang dilakukan oleh perusahaan akan menambah pendapatan sehingga berimbas pada perolehan kas, apabila penjualan dilakukan secara tunai, atau bahkan akan menambah piutang apabila dilakukan secara kredit. Tujuan tercapainya penjualan yang dapat dikonversikan ke dalam kas, digunakan untuk membiayai semua aktivitas perusahaan. Hal ini membuat perusahaan akan mengatur sistem informasi akuntansi yang berkaitan dengan penjualan secara kredit yang menimbulkan piutang yang telah berjalan di perusahaan, agar mencapai hasil output informasi yang baik dan menghasilkan laporan penerimaan kas yang teratur dari hasil penagihan piutang.

Piutang merupakan salah satu aktiva besar yang sangat penting untuk diperhatikan karena berpengaruh pada likuiditas perusahaan. Ini sebab piutang masuk dalam kategori aset lancar dan diharapkan akan dapat dicairkan dalam waktu singkat. Tanpa adanya pencatatan dan pengawasan yang baik, kesalahan dan penyelewengan terhadap piutang akan mudah terjadi.
Prosedur pencatatan piutang bertujuan untuk mencatat mutasi piutang perusahaan kepada setiap debitur. Mutasi piutang disebabkan oleh transaksi penjualan kredit, penerimaan kas dari debitur, retur penjualan, dan penghapusan piutang.

Dalam akuntansi piutang, secara periodik dihasilkan pernyataan piutang yang dikirimkan kepada setiap debitur. Pernyataan piutang ini merupakan unsur pengendalian internal yang baik dalam pencatatan piutang. Dengan mengirimkan secara periodik pernyataan piutang kepada para debitur, catatan piutang perusahaan diuji keakuratannya dengan menggunakan tanggapan yang diterima dari debitur atas pengiriman pernyataan piutang tersebut. (Mulyadi, 2016)

Perusahaan-perusahaan yang bergerak pada penjualan sepeda motor yang terdiri terdiri atas penjualan tunai dan penjualan kredit yang menimbulkan piutang. Perusahaan ini sebagai penyedia barang dan bekerjasama dengan lembagalembaga pembiayaan kredit atau yang biasa disebut leasing. Dimana untuk setiap penjualan kredit akan terbentuk piutang leasing. Sesuai dengan kesepakatan dealer dan leasing, piutang akan dibayarkan maksimal 10 hari dari sepeda motor diterima konsumen atas kesepakatan pembiayaan $90 \%$ dari penjualan sepeda motor.

Perusahaan - perusahaan dalam melakukan penjualan kredit dihadapkan pada permasalahan piutang yang tidak dibayarkan tepat waktu sebesar 10 hari pasca pengiriman barang. Jelas bahwa perusahaan dihadapkan pada problematik piutang 
yang berpotensi mempengaruhi kas masuk. Untuk itu perusahaan harus dapat melakukan kontrol piutang dengan melihat umur piutang berjalan. Kesalahan dan penyelewengan terhadap piutang yang tidak dapat dicairkan dalam waktu singkat maka akan mengganggu kelancaran operasi perusahaan secara keseluruhan. Hal ini dapat terjadi dikarenakan belum adanya output sistem yang mampu menyajikan laporan piutang lengkap dengan umur piutang berjalan dan data pendukung penagihan piutang. Dimana untuk kontrol dan pelaporan piutang, pihak admin harus menghitung umur piutang berjalan secara manual. Tentunya hal ini akan menyulitkan bagian penagihan piutang untuk mengontrol piutang secara up to date setiap harinya. Pelaporan follow up piutang berjalan terhadap pihak leasing juga harus dilakukan penarikan data piutang dan data penjualan yang kemudian harus diolah lagi menggunakan Microsoft excel. Dimana sistem serta output sistem yang ada belum bisa menghasilkan laporan yang dibutuhkan sesuai kebutuhan perusahaan.

Penelitian yang dilakukan oleh Tri Setyawati (2013) dengan judul Sistem Informasi Pembayaran Piutang Pada PT Abadi Surya dengan Microsoft Visual Basic, menyatakan bahwa program sistem infromasi pembayaran piutang yang dapat memudahkan dalam mengontrol piutang.

Ika Kurniati (2011), dengan judul penelitiannya "Analisis dan Perancangan Sistem Informasi Akuntansi Piutang Usaha Terkomputerisasi pada Primer Koperasi Kepolisian Korps Brimob (PRIMKOPPOL Korps Brimob)", menyatakan bahwa mengaplikasi sistem akuntansi piutang usaha terkomputerisasi mampu melakukan fungsi pencatatan transaksi piutang usaha mulai dari input data pinjaman anggota, input pembayaran angsuran, pencarian data dan pembuatan laporan.

Berdasarkan hasil penelitian dari beberapa peneliti yang telah diuraikan, penulis mengembangkan sistem yang ada dengan sistem penagihan berbasis web yang bisa diakses secara multiuser. Dengan pengembangan sistem ini, pihak dealer bisa melakukan kontrol piutang dengan lebih mudah. Penagihan piutang berjalan tidak perlu dilakukan secara manual, namun pihak leasing bisa mengakses piutang berjalan dengan user leasing yang bersangkutan. Untuk pihak leasing sendiri juga bisa lebih cepat dalam memberikan reason piutang berjalan belum terbayar dengan penginputan data pada web yang akan dikembangkan. Melihat pentingnya pengembangan sistem pada perusahaanperusahaan yang melakukan penjualan kredit maka, peneliti berkeinginan untuk merancang Sistem Pencatatan dan Monitoring Piutang Leasing Berbasis $W e b$.

\subsection{Rumusan Masalah}

a. Bagaimana merancang sistem Pencatatan dan monitoring piutang leasing yang efektif dan efisien?

b. Bagaimana merancang sistem Pencatatan dan monitoring piutang leasing yang valid?

\subsection{Tujuan}

a. Untuk merancang sistem Pencatatan dan monitoring piutang leasing yang efektif dan efisien.

b. Untuk merancang sistem Pencatatan dan monitoring piutang leasing yang valid.

\subsection{Landasan Teori}

\section{a. Sistem}

Menurut Sutarman (2012), "Sistem adalah kumpulan elemen yang saling berhubungan dan berinteraksi dalam satu kesatuan untuk menjalankan suatu proses pencapaian suatu tujuan utama". Menurut Taufiq (2013), "Sistem adalah sekumpulan dari sub-sub sistem abstrak maupun fisik yang saling terintegrasi dan berkolaborasi untuk mencapai suatu tujuan tertentu". Pendapat lain menurut Romney, John (2014), "Sistem adalah serangkaian dua atau lebih komponen yang saling berkaitan dan berinteraksi untuk mencapai tujuan", sedangkan menurut Sutabri (2012), "Sistem dapat diartikan sebagai suatu kumpulan atau himpunan dari unsur, komponen, atau variabel yang terorganisir, saling berinteraksi, saling bergantung satu sama lain, dan terpadu".

Dari beberapa pendapat yang telah disebutkan, dapat disimpulkan bahwa sistem merupakan kumpulan atas bagian-bagian yang berkerja sama dan berkaitan untuk mencapai tujuan..

\section{b. Flowchart}

Indrajani (2015), “Flowchart adalah penggambaran secara grafik dari langkah-langkah dan urutan prosedur suatu program."

\section{c. $\quad E R D$}

Menurut Shalahudin (2014), "ERD (Entity Relationship Diagram) adalah pemodelan awal basis data yang akan dikembangkan berdasarkan teori himpunan dalam bidang matematika untuk pemodelan basis relasional".

\section{d. Normalisasi}

Menurut Fathansyah (2012), "Normalisasi merupakan peralatan yang digunakan untuk melakukan proses pengelompokan data menjadi tabel-tabel yang menunjukan entitas dan relasinya".

\section{e. DFD}

Menurut Shalahuddin (2014), "DFD (Data Flow Diagram) atau dalam bahasa Indonesia menjadi DAD (Diagram Alir Data) adalah 
representasi grafik yang menggambarkan aliran informasi dan transformasi informasi yang diaplikasikan sebagai data yang mengatur dari masukan (input) dan keluaran (output). DFD tidak sesuai untuk memodelkan sistem pemrograman berorientasi objek."

\section{f. Database}

Menurut Sutarman (2012) Database adalah sekumpulan file yang saling berhubungan dan terorganisasi atau kumpulan record-record yang menyimpan data dan hubungan diantaranya, sedangkan menurut Ladjamudin (2013), database adalah sekumpulan data store (bisa dalam jumlah yang sangat besar) yang tersimpan dalam magnetic disk, oftical disk, magnetic drum, atau media penyimpanan sekunder lainnya.

Dari pengertian diaatas dapat disimplakan bahwa database adalah sekumpulan file yang menyimpan data yang saling berhubungan dan tersimpan di media penyimpanan.

\section{g. Kredit}

Sacara etimalogi, istilah kredit berasal dari Bahasa latin, yaitu "credere", yang berarti kepercayaan.

Dalam kamus Besar Bahasa Indonesia, kredit adalah pinjaman sampai batas jumlah tertentu yang diizinkan oleh bank atau badan lain. Beberapa definisi kredit yang dikemukakan oleh para ahli ekonomi, yaitu :

Kredit pada perkembangannya mengarahkan fungsinya untuk merangsang kedua belah pihak untuk tujuan pencapaian kebutuhan baik dalam bidang usaha, maupun kebutuhan sehari-hari. Pihak yang mendapatkan kredit harus dapat menunjukkan prestasi yang lebih tinggi pada kemajuan usahanya itu, atau mendapatkan rentabilitas berdasarkan perhitungan yang wajar dari modal yang dijadikan objek kredit, dan secara spiritual mendapatkan kepuasan karena dapat membantu pihak lain untuk mencapai kemajuan (Kasmir, 2007).

Adapun pengertian kredit menurut UU Perbankan No.7 tahun 1992 :

"Kredit adalah penyediaan uang atau tagihan yang dapat dipersamakan dengan itu, berdasarkan persetujuan atau kesepakatan pinjam meminjam antara suatu perusahaan dengan pihak lain yang mewajibkan pihak peminjam untuk melunasi hutangnya setelah jangka waktu tertentu dengan jumlah uang, imbalan atau pembagian hasil keuntungan."

\section{h. Piutang}

Menurut Syamsudin (2007:255) "Piutang adalah tagihan yang timbul karena adanya transaksi secara kredit oleh perusahaan kepada langganannya".

Penjualan kredit yang pada akhirnya akan menimbulkan hak penagihan atau piutang kepada langganan, sangat erat hubungannya dengan persyaratan-persyaratan kredit yang diberikan. Sekalipun pengumpulan piutang sering kali tidak tepat waktu yang sudah ditetapkan, namun sebagian besar dari piutang tersebut akan terkumpul dalam jangka waktu kurang dari 1 tahun. Dengan alasan itulah, maka piutang dimasukan sebagai salah satu komponen dalam aktiva lancar perusahaan.

Warren dan Fess (2005;404) menyatakan bahwa piutang meliputi semua klaim dalam bentuk uang terhadap pihak lainnya, termasuk individu, perusahaan atau organisasi lainnya. Menurut Alexandri (2009:117) piutang adalah sejumlah uang hutang dari konsumen pada perusahaan yang membeli barang dan jasa secara kredit pada perusahaan. Piutang lancar diharapkan dapat tertagih dalam satu tahun atau selama setahun operasional berjalan. Semua piutang dikelompokkan sebagai piutang tidak lancar.

\section{i. Jenis Piutang}

Siahaan (2010) menyebukan bahwa untuk tujuan pelaporan keuangan, piutang diklarifikasikan sebagai lancar (jangka pendek) dan tidak lancar (jangka panjang). Piutang lancar (current receivable) diharapkan akan tertagih dalam satu tahun selama satu siklus operasional. Sedangkan selain itu dikatakan sebagai piutang tidak lancar. Lembaga Pembiayaan

Lembaga Pembiayaan menurut Kepres RI No.61 tahun 1988, pasal 1 ayat 2 pembiayaan adalah "Badan usaha yang melakukan kegiatan pembiayaan dalam bentuk penyediaan barang atau dana dengan tidak menarik dana secara langsung dari masyarakat (Giro, Deposito, Tabungan dll)".

Lembaga pembiayaan mempunyai beberapa bidang usaha, yaitu :

a) Perusahaan Sewa Guna Usaha (Leasing Company)

Badan usaha ini melakukan pembiayaan dalam bentuk penyediaan barang modal, baik secara finance lease maupun operating lease, untuk digunakan oleh penyewa guna usaha jangka waktu tertentu berdasarkan pembiayaan secara berkala.

b) Perusahaan Modal Ventura (Venture Capital Company)

Badan usaha ini melakukan usaha pembiayaan dalam bentuk penyertaan modal ke dalam satu perusahaan yang menerima bantuan pembiayaan untuk jangka waktu tertentu.

c) Perusahaan Jasa Anjak Piutang (Factori $n g$ Company)

Badan usaha ini merupakan badan yang melakukan usaha pembiayaan dalam bentuk pembeliaan dan atau penagihan pengurusan piutang atau tagihan jangka pendek suatu perusahaan dari transaksi perdagangan dalam dan luar negeri. 
d) Perusahaan Pembiayaan Konsumen (Consumer Finance Company)

Badan usaha ini melakukan pembiayaan untuk membeli barang dan jasa dengan menggunakan kartu kredit.

e) Perusahaan Perdagangan Surat Berharga (Securities Company)

Badan usaha ini melakukan pembiayaan dalam bentuk perdagangan surat berharga.

\section{j. $\quad$ PHP}

PHP merupakan bahasa standar yang digunakan dalam dunia website. PHP adalah bahasa program yang berbentuk script yang diletakkan dalam server web. Hampir semua aplikasi berbasis web dapat dibuat dengan PHP, fungsi PHP adalah menghubungkan database dengan web. Dengan PHP, membuat aplikasi web yang terkoneksi ke database menjadi lebih mudah. Sistem database yang telah didukung oleh PHP adalah Oracle, Sybase, MySQL, Solid, GenerigODBC, PostgreSQL (Nugroho, 2008).

\section{k. MySQL}

Menurut Sidik (2012), "MySQL merupakan software database yang termasuk paling popular di lingkungan linux, kepopuleran ini karena performasi query dari database yang saat itu bisa dikatakan paling cepat, dan jarang bermasalah".

\subsection{Metode Penelitian}

Metode yang digunakan dalam penelitian ini adalah metode R\&D (Research and Development). Penelitian dan pengembangan adalah suatu proses atau langkah-langkah untuk mengembangkan suatu produk baru atau menyempurnakan produk yang telah ada. Yang dimaksud dengan produk dalam konteks ini adalah perangkat lunak (software) seperti program untuk pengolahan data. Skripsi ini menggunakan model Penelitian Pengembangan Research and Development (R\&D) yang biasa disebut juga dengan Research-Based Development (Borg, \& Gall) atau pengembangan berbasis penelitian yaitu proses yang digunakan untuk mengembangkan dan memvalidasi produk-produk pendidikan. Metodologi penelitian diartikan sebagai cara ilmiah untuk mendapatkan data dengan tujuan dan kegunaan tertentu (Sugiyono : 2013).

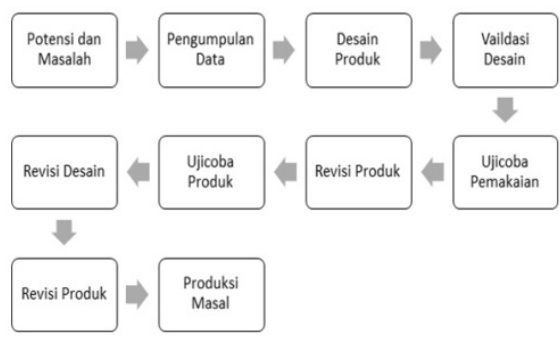

Gambar 1a Metode R\&D

(Sumber: Sugiyono, 2013)

Langkah-langkah tersebut secara ringkas dijelaskan sebagai berikut :

a. Potensi dan Masalah

Penelitian berawal dari adanya potensi atau masalah. Potensi adalah segala sesuatu yang bila didayagunakan akan memiliki nilai tambah. Masalah juga bisa dijadikan sebagai potensi, apabila dapat mendayagunakannya. Masalah akan terjadi jika terdapat penyimpangan antara yang diharapkan dengan yang terjadi. Masalah ini dapat diatasi melalui R\&D dengan cara meneliti sehingga dapat ditemukan suatu model, pola atau sistem penanganan terpadu yang efektif yang dapat digunakan untuk mengatasi masalah tersebut. Potensi dan masalah yang dikemukakan dalam penelitian harus ditunjukkan dengan data empirik. Data tentang potensi dan masalah tidak harus dicari sendiri, tetapi bisa berdasarkan penelitian orang lain atau dokumentasi laporan kegiatan perorangan atau perusahaan tertentu yang masih up to date.

b. Mengumpulkan informasi

Setelah potensi dan masalah dapat ditunjukkan faktual dan up to date, selanjutnya dikumpulkan berbagai studi dan literatur yang dapat digunakan sebagai bahan untuk perencanaan produk tertentu yang diharapkan dapat mengatasi masalah tersebut. Studi ini ditujukan untuk menemukan konsep - konsep atau landasan - landasan teoritis yang memperkuat suatu produk, khususnya yang terkait dengan produk pendidikan, misalnya produk yang berbentuk model, program, sistem, pendekatan, software dan sebagainya. Disisi lain melalui studi literatur akan dikaji ruang lingkup suatu produk, keluasan pengguna, kondisi kondisi pendukung agar produk dapat digunakan atau diimplementasikan secara optimal, serta keunggulan dan keterbatasannya. Studi literatur juga diperlukan untuk mengetahui langkah langkah yang paling tepat dalam pengembangan produk tersebut.

c. Desain Produk

Desain produk yang dihasilkan dari R\&D ada banyak macamnya. Untuk menghasilkan sistem kerja baru, harus dibuat rancangan kerja baru berdasarkan penilaian terhadap sistem kerja lama, sehingga dapat ditemukan kelemahan kelemahan terhadap sistem tersebut. Disamping itu dilakukan penelitian terhadap unit lain yang dipandang sistem kerjanya bagus. Selain itu harus mengkaji referensi mutakhir yang terkait dengan sistem kerja yang modern berikut indikator sistem kerja yang baik. Hasil akhir dari kegiatan ini berupa desain produk baru yang lengkap dan spesifikasinya. Desain ini masih bersifat hipotetik karena efektifitasnya belum 
terbukti, dan akan dapat diketahui setelah melalui pengujian-pengujian. Desain produk harus diwujudkan dengan gambar atau bagan, sehingga dapat digunakan sebagai pegangan untuk menilai dan membuatnya, serta akan memudahkan pihak lain untuk memahaminya.

d. Validasi Desain

Validasi desain merupakan proses kegiatan untuk menilai apakah rancangan produk, dalam hal ini sistem kerja baru secara rasional akan lebih efektif dari yang lama atau tidak. Dikatakan secara rasional karena validasi disini masih bersifat penilaian berdasarkan penilaian rasional, belum fakta lapangan. Validasi produk dapat dilakukan dengan menghadirkan beberapa pakar atau tenaga ahli yang sudah berpengalaman untuk menilai desain tersebut, sehingga selanjutnya dapat diketahui kelemahan dan kekuatannya. Sebelum diskusi peneliti mempresentasikan proses penelitian sampai ditemukan desain tersebut, berikut keunggulannya.

e. Perbaikan Desain

Setelah desain produk, divalidasi melalui diskusi dengan pakar dan para ahli lainnya, maka akan diketahui kelemahannya. Kelemahan tersebut selanjutnya dicoba untuk dikurangi dengan cara memperbaiki desain. Yang bertugas memperbaiki desain adalah peneliti.

f. Uji Coba Produk

Desain produk yang telah dibuat tidak bisa langsung diuji coba dahulu, menghasilkan produk dan produk tersebut yang diuji coba. Pengujian dapat dilakukan dengan eksperimen yaitu membandingkan efektivitas dan efisiensi sistem kerja lama dengan yang baru.

g. Revisi Produk

Penguji produk pada sampel yang terbatas tersebut menunjukkan bahwa kinerja sistem kerja baru ternyata yang lebih dari sistem lama. Perbedaan sangat signifikan, sehingga sistem kerja baru tersebut dapat diberlakukan.

h. Uji Coba Pemakaian

Setelah pengujian terhadap produk berhasil, dan mungkin ada revisi yang tidak terlalu penting, maka selanjutnya produk yang berupa sistem kerja baru tersebut diterapkan dalam kondisi nyata untuk lingkup yang luas. Dalam operasinya sistem kerja baru tersebut diterapkan dalam kondisi nyata untuk lingkup yang luas. Dalam operasinya sistem kerja baru tersebut, tetap harus dinilai kekurangan atau hambatan yang muncul guna perbaikan lebih lanjut

i. Revisi Produk
Revisi Produk ini dilakukan, apabila dalam perbaikan kondisi nyata terdapat kekurangan dan kelebihan. Dalam uji pemakaian, sebaiknya pembuat produk selalu mengevaluasi bagaimana kinerja produk.

j. Pembuatan Produk Masal

Pembuatan produk masal ini dilakukan apabila produk yang telah diuji coba dinyatakan efektif dan layak diproduksi masal.

\subsection{Perancangan Sistem}

a. Flow Of Document

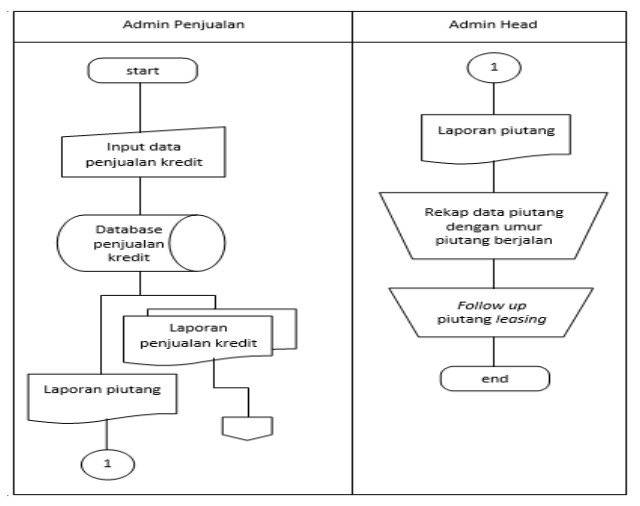

Gambar 1b. Alur Sistem Lama Sumber : Data Primer

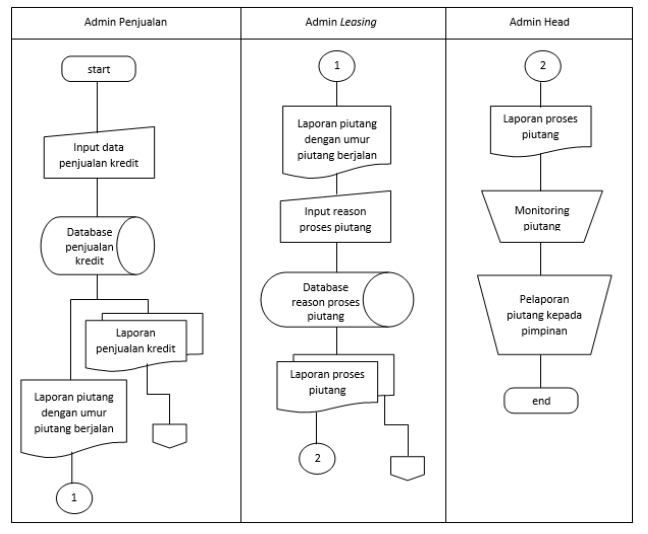

Gambar 1c. Alur Sistem Baru Sumber : Data Primer

\section{b. Data Flow Diagram}




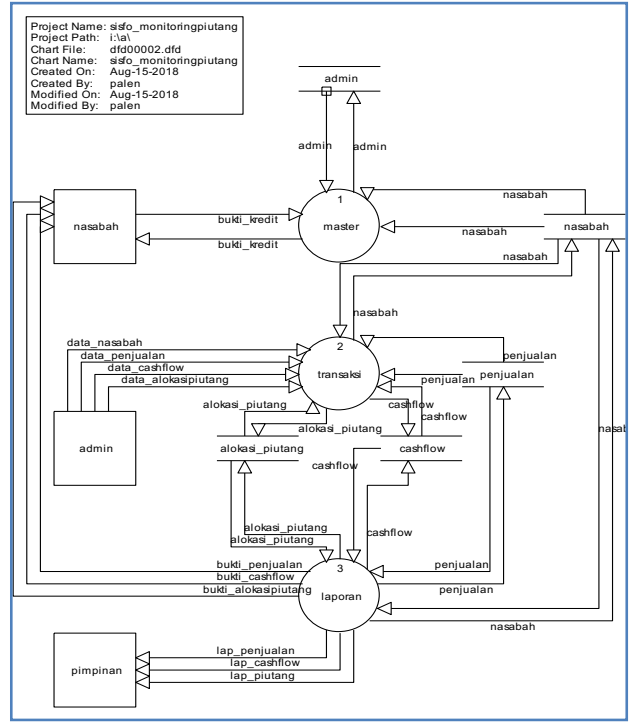

Gambar 1d. DFD Level 0 Sumber : Data Primer

c. Normalisasi

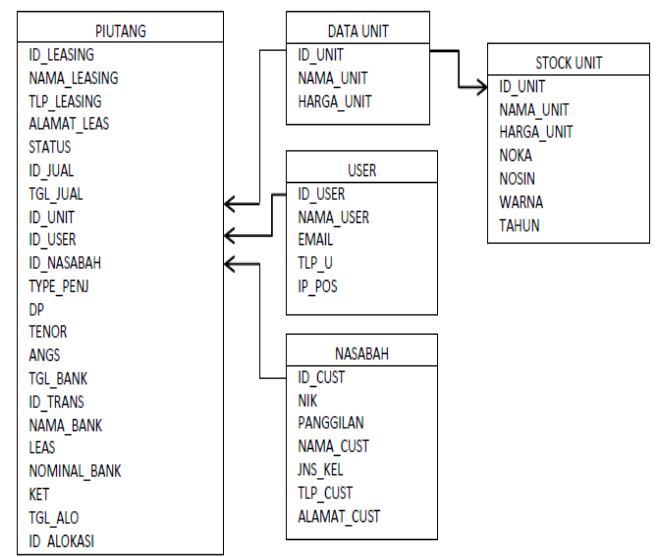

Gambar 1e. Normalisasi

Sumber : Data Primer

d. ERD

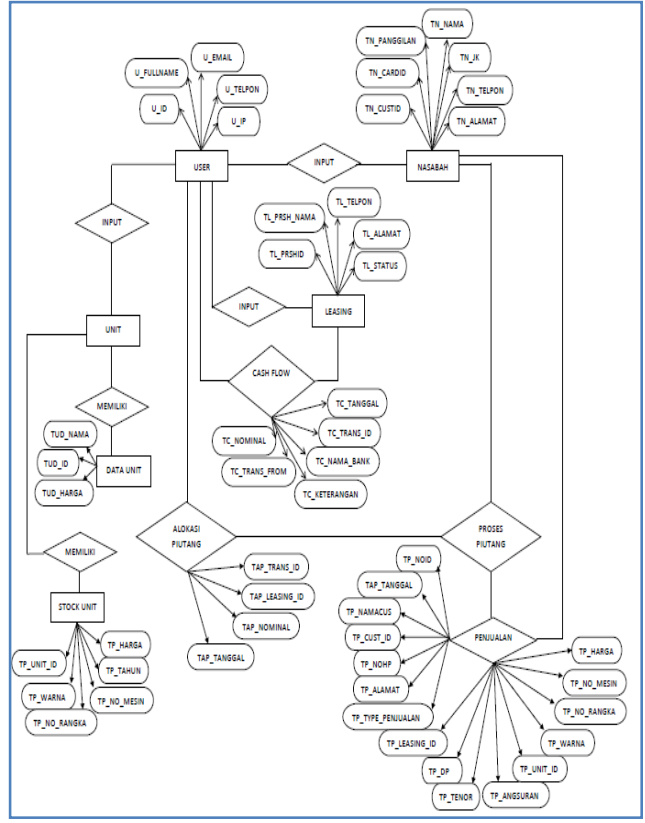

Gambar 1f. ERD

Sumber : Data Primer

\section{PEMBAHASAN}

\section{$2.1 \quad$ Hasil}

Hasil dari penelitian ini berupa (software) Sistem Informasi yang mencatat data penjualan kredit yang membentuk piutang leasing. Admin dealer akan mengolah data penjualan kredit berdasarkan masing-masing leasing yang menyetujui kredit nasabah. Adapun Macromedia Dreamweaver dipakai untuk membangun interface atau form-form, PHP sebagai bahasa pemrograman yang digunakan dan Mysql untuk menampung databasenya.

\subsection{Implementasi Program}

a. Halaman Utama

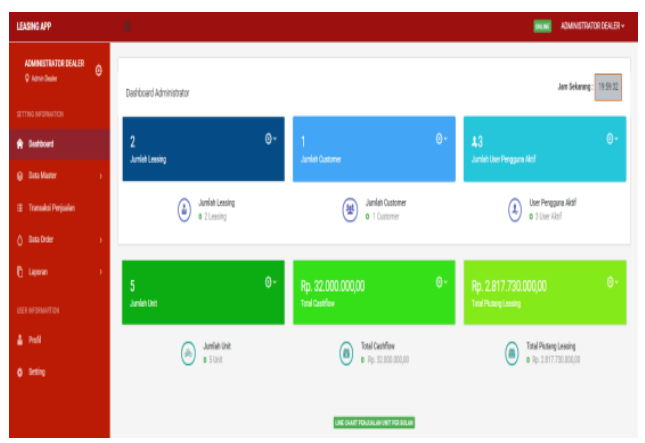

Gambar 2a. Halaman Utama Sumber : Data Primer 
Sumber : Data Primer

b. Halaman Input Data Konsumen

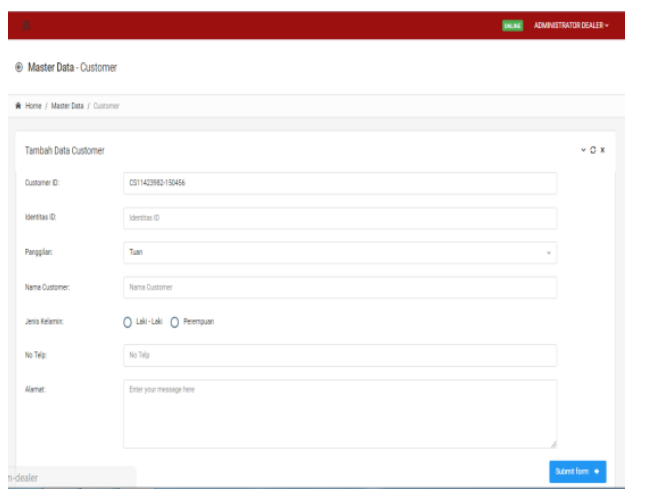

Gambar 2b. Halaman Input Data Konsumen Sumber : Data Primer

c. Halaman Konfirmasi Order (leasing)

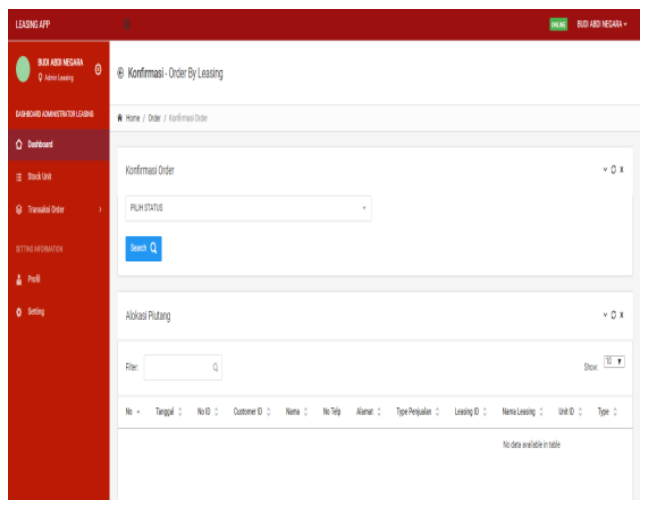

Gambar 2c. Halaman Konfirmasi Order (leasing) Sumber : Data Primer

\section{d. Halaman Login}

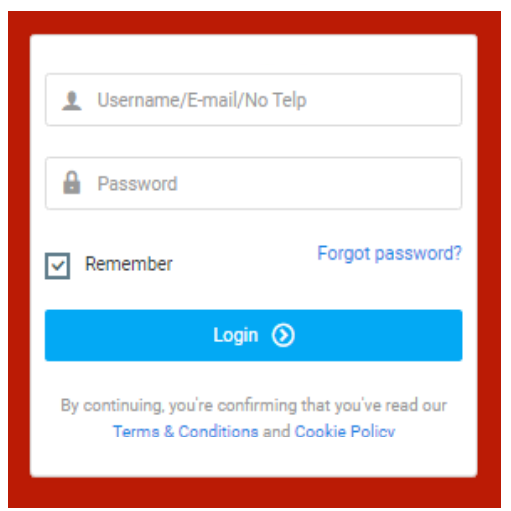

Gambar 2d. Halaman Login e. Halaman Input Transaksi Penjualan

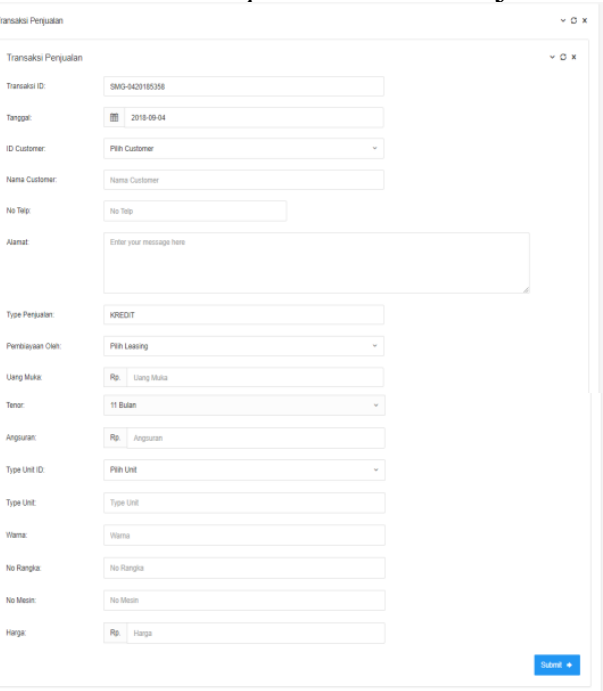

Gambar 2e. Input Transaksi Penjualan Sumber : Data Primer

e. Halaman Alokasi Piutang

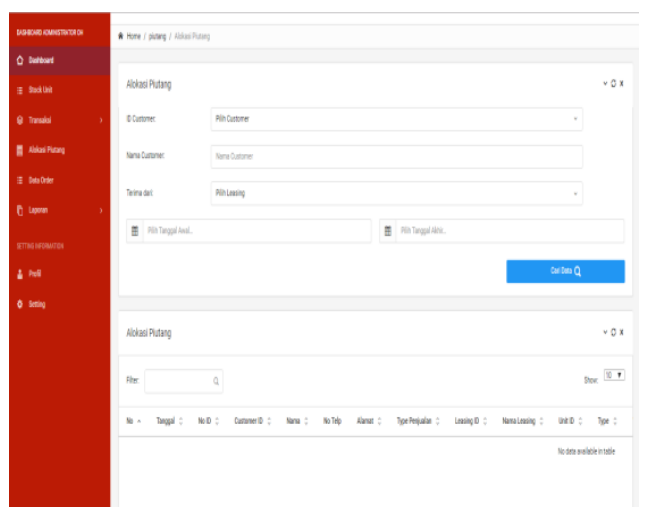

Gambar 2f. Halaman Alokasi Piutang Sumber : Data Primer

\section{KESIMPULAN}

Dari uraian pembahasan diatas mengenai Sistem Pencatatan Dan Monitoring Piutang Leasing Berbasis $W e b$, maka dapat disimpulkan bahwa:

1. Sistem pencatatan dan monitoring piutang leasing berbasis web sangat dibutuhkan bagi 
perusahaan dalam mengontrol piutang leasing.

2. Sistem pencatatan dan monitoring piutang leasing berbasis web dapat memudahkan admin head dalam mengontrol piutang leasing dan memudahkan pihak leasing untuk memberikan konfirmasi proses piutang hingga terbayarkan.

3. Sistem pencatatan dan monitoring piutang leasing berbasis web ini memudahkan admin head dalam mengolah data piutang sehingga laporan piutang berjalan dapat dilakukan dengan cepat.

\section{PUSTAKA}

Alexandri, Moh., 2009, Manajemen Keuangan Bisnis. Cetakan Kesatu. Bandung, Alfabeta

Fathansya, 2012, Basis Data, Bandung : Informatika.

Fees, Reeve, Warren, 2005, Pengantar Akuntansi, Edisi 21.Jakarta, Salemba Empat.

Indrajani, 2015. Database Design (Case Study All in One). Jakarta, PT. Elex Media Komputindo.

Kurniati, Ika, 2011, Analisis \& Perancangan Sistem Informasi Akuntansi Piutang Usaha Terkomputerisasi Pada Primer Koperasi.

Kasmir, 2007. Dasar-Dasar Perbankan Jakarta : PT Raja Grafindo Persada.

Keputusan Presiden Nomor 61Tahun 1988 Lembaran Negara RI Tahun 1988No.53 tentang Lembaga Pembiayaan.

Ladjamudin, Al - Bahra Bin. 2013. Analisis dan Desain Sistem Informasi. Jakarta : Bumi Aksara.

Mulyadi, 2016. Sistem Akuntansi (Edisi 4 ). Jakarta : Penerbit Salemba Empat.
Nugroho, Bunafit, 2008, Aplikasi Pemrograman Web Dinamis Dengan PHP dan MySQL. Yogyakarta , GavaMedia.

Romney, B, 2014, Sistem Informasi Akuntansi (Edisi $k e-13$ ). Jakarta , Penerbit Salemba Empat.

Setyawati, Tri, 2013, Sistem Informasi Pembayaran Piutang Pada PT Abadi Surya.

Shalahuddin, M., 2014, Rekayasa Perangkat Lunak Struktur dan Berorientasi Objek.Bandung , Informatika.

Siahaan, Debora. 2010. Analisis Penerapan Kebijakan Piutang serta Pengaruhnya Terhadap cash ratio, net profit margin, dan earning power Pada Perusahaan PT. Wijaya Indonesia Makmur Bicycle Industry Cabang Setia Budi Medan. Skripsi, Universitas Sumatera Utara, Medan.

Sidik, Bertha., 2014, Pemrograman Web dengan Php. Solo, Santika Kencana.

Sugiyono, 2013. Metode Penelitian Pendidikan Pendekatan Kuantitatif, Kualitatif, dan R\&D. Bandung, Alfabeta.

Sutabri, Tata, 2012. Analisis Sistem Informasi. Yogyakarta : Andi.

Sutarman, 2012, Buku Pengantar Teknologi Informasi, Jakarta, Bumi Aksara.

Syamsuddin, Lukman, 2007, Manajemen Keuangan Perusahaan, Konsep Aplikasi dalam Perencanaan, Pengawasan, dan Pengambilan Keputusan. Jakarta, PT Raja Grafindo Persada.

Taufiq, 2013, .Sistem Informasi Manajemen Konsep Dasar, Analisis dan Metode Pengembangan. Yogyakarta : Graha Ilmu.

Undang-Undang No. 7 Tahun 1992 Tentang Perbankan. 